\title{
Sýking af völdum nókardíu í ónæmisbældum einstaklingi
}

\begin{abstract}
Ágrip
Hilmir Inngangur: Nókardía er baktería sem getur Ásgeirsson ${ }^{1}$ sýkt ónæmisbælda. Nókardíusýking í lungum ææknir ${ }^{1}$ er algengust en bakterían getur dreifst til fleiri líffæra.

Bryndís

Sigurðardóttir²

smitsjúkdómalæknir

Sjúkratilfelli: 92 ára karl með pvagblöðrukrabbamein og á sterameðferð hafði tveggja vikna sögu um bólgu á hendi og vitrænar breytingar. Fyrirferð greindist í heila og hnútar í lungum en frá greftri úr hendi óx Nokardia farcinia. Sýkingin var meðhöndluð með sýklalyfjum en síðar veitt líknandi meðferð.
\end{abstract}

Lykilorð: nókardíusýki, nókardía, ónæmisbæling.

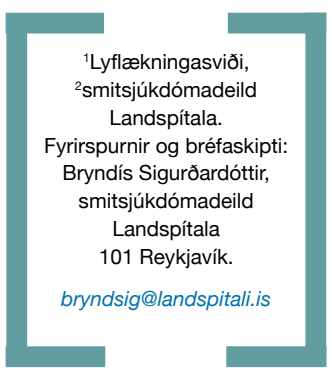

Ályktun: Mikilvægt er að vera vakandi fyrir óvenjulegum sýkingum í ónæmisbældum einstaklingum á Íslandi.

\section{Sjúkratilfelli}

92 ára karlmaður leitaði á bráðamóttöku vegna tveggja vikna vaxandi roða og bólgu á hægra handarbaki án sögu um áverka. Pessu fylgdi slappleiki en hann taldi sig ekki hafa haft hita. Vegna gruns um húðsýkingu hafði hann verið settur á díkloxacillín $\left(\right.$ Staklox$\left.^{\circledast}\right)$ sex dögum fyrr en einungis tekið nokkrar töflur par sem honum hafði gengið illa að gleypa pær. Síðustu viku hafði auk pess borið á vaxandi rugli og óstöðugleika en vitræn geta hafði verið góð fram til pessa. Markvert 1 heilsufari var pvagblöðrukrabbamein með pekktu meinvarpi í spjaldbeini sem hafði verið geislað. Einnig var grunur um lungnameinvörp en á tölvusneiðmynd tveimur mánuðum fyrr höfðu sést hnútóttar péttingar í lungum. Hann var ekki á virkri krabbameinslyfjameðferð en tók prednisólon $10 \mathrm{mg}$ á dag auk verkjalyfja.

Við skoðun var sjúklingur vel áttaður og ekki bráðveikindalegur. Hiti var $37,9^{\circ} \mathrm{C}$ (mælt í holhönd) og púls 68 slög á mínútu. Yfir stórum hluta hægra handarbaks sást fyrirferð sem var aum viðkomu og dúaði. Roði var á húð og náði upp priðjung framhandleggs og yfir í lófa (mynd 1). Eymsli voru yfir neðsta hluta lendhryggjar og efri hluta spjaldbeins. Í blóði voru hvítkorn $21 \times 10^{9} / 1$ $(4,0-10,5)$, par af voru kleyfkjarna frumur $19 \times 10^{9} / 1$ $(4,0-10,5)$, CRP $155 \mathrm{mg} / 1$ (<3) og sökk $71 \mathrm{~mm} / \mathrm{klst}$ (<23). Röntgenmynd af hægri hendi sýndi ekki merki um beinbreytingar. Handarskurðlæknir opnaði inn á fyrirferðina og út vall mikill gröftur sem sendur var í ræktun. Skilinn var eftir keri og meðferð hafin með cefazólíni $\left(K_{e f z o l}{ }^{\circledR}\right)$ í æð.

Næstu daga hjaðnaði bólgan nokkuð og sjúklingur var hitalaus en talsvert bar á óáttun og ruglástandi. Á tölvusneiðmynd af heila sást fyrirferð hægra megin í hnakkablaði og var hún $3 \times 2$ $\mathrm{cm}$ í pvermál (mynd 2). Röntgenmynd af lungum sýndi hnútóttar breytingar, sú stærsta um einn $\mathrm{cm}$ að pvermáli í ofanverðu hægra lunga. Á fjórða degi var tilkynnt að úr greftri yxi nókardía og var í kjölfarið staðfest að um Nocardia farcinia væri að ræða. Hafin var meðferð með trímetóprím/ súlfa 480mg x2 á dag í æð í stað cefazólíns og steraskammtar minnkaðir. Vegna almenns lélegs ástands var ákveðið að bíða með frekari uppvinnslu á fyrirferð í heila og hnútum í lungum. Skipt var yfir í töflumeðferð með trímetóprími/

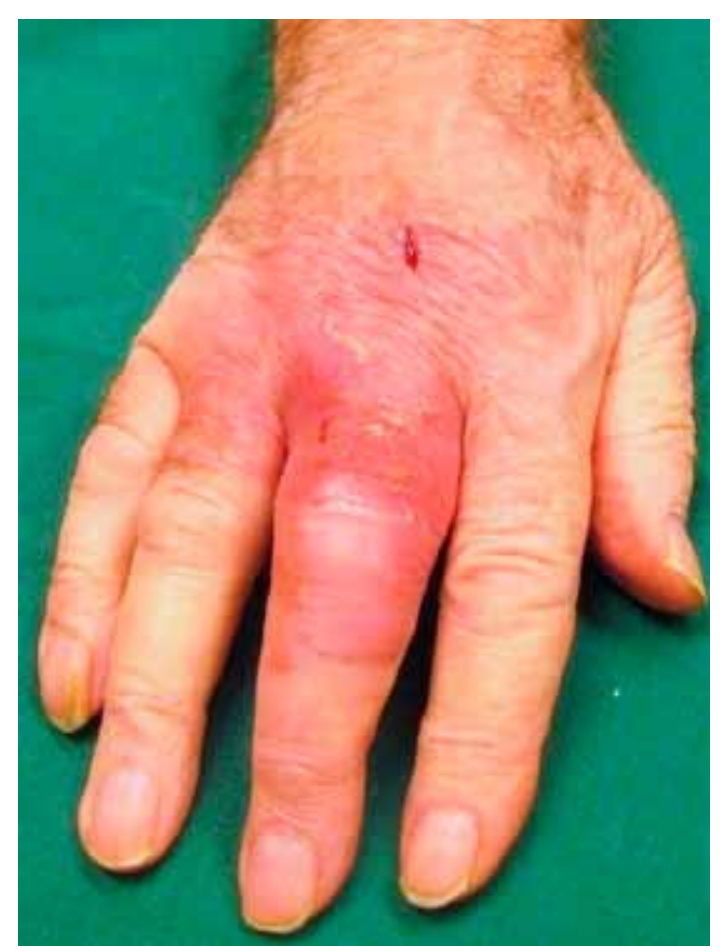

Mynd 1. Roði og bólga í húð. Á miðju handarbaki sjást ummerki eftir ísetningu kera. Mynd tekin á fimmta degi innlagnar. (Mynd: Bryndis Sigurðardóttir.) 
Mynd 2. Tölvusneiðmynd af heila. Í hrogra hnakkablaði sést $3 \times 2 \mathrm{~cm}$ fyrirferð (ör) sem hefur randstæða skuggaefnisupphleðslu og aðlæcgan bjúg

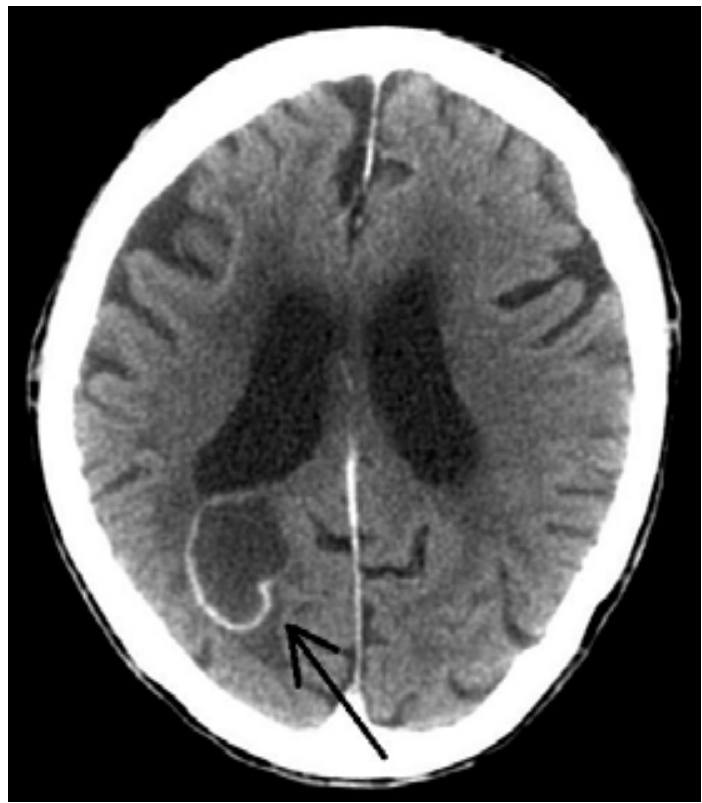

súlfa 960mg x2 á dag tveimur vikum síðar, en sjúklingi gekk illa að kyngja töflunum og óvíst hve mikið hann tók. Honum hrakaði áfram og um sex vikum eftir greiningu var ákveðið að hætta sýklalyfjameðferð, enda pá kominn heim á vegum líknarteymis. Hann lést viku síðar.

\section{Umræða}

Nókardía er jarðvegsbaktería sem getur valdið sýkingum hjá mönnum. ${ }^{1,2}$ Yfir 50 tegundir af nókardíu hafa greinst og er um helmingur talinn mögulegur sýkingavaldur. ${ }^{1}$ Algengastar 1 mönnum eru N. asteroides, $N$. farcinica, N. nova, $N$. transvalensis og N. brasiliensis. ${ }^{3}$

Erfitt er að áætla nýgengi nókardíusýki. Flestar sýkingar verða í ónæmisbældum pó að vel sé pekkt að fólk með heilbrigt ónæmiskerfi geti sýkst. 1, 3, 4 Talið er að í Bandaríkjunum greinist að minnsta kosti 1000 tilfelli á ári og hefur peim fjölgað verulega á síðustu áratugum samfara fjölgun ónæmisbældra einstaklinga. ${ }^{3}$ Sérstakir áhættuhópar eru líffærapegar, krabbameinssjúklingar og lungnasjúklingar en meirihluti peirra sem sýkjast eru á meðferð með barksterum. ${ }^{3,4}$ Í sjúkratilfellinu var einmitt um að ræða háaldraðan einstakling á barksterameðferð í tengslum við útbreitt krabbamein. Höfundar hafa vitneskju um að nókardía hafi líklega greinst tvisvar sinnum áđur á Íslandi, án pess að hafa nánari upplýsingar um pau tilfelli.

Lungnasýkingar eru algengasta form nókardíusýki. ${ }^{1,3,4}$ Talið er að smit eigi sér stað við innöndun ryks eða annarra agna sem innihalda bakteríurnar. Einkenni koma yfirleitt fram á nokkrum dögum til vikum. Hiti, hósti og mæði eru helstu einkenni og oft fylgir pykkur uppgang- ur. Prekleysi og pyngdartap eru einnig algeng. ${ }^{1,4,5}$ Breytingar á lungnamynd geta verið allt frá litlum hnútum til dreifðra íferða með holumyndunum (e. cavitation)., ${ }^{3,5}$ Algengt er að breytingarnar séu í efri löppum lungna. ${ }^{3}$ Sýkingin getur auk pess dreift sér staðbundið og valdið gollurshússbólgu og miðmætisbólgu. ${ }^{1}$ Í um helmingi allra lungnasýkinga nær bakterían að dreifa sér með blóði til annarra líffæra. Algengast er að hún dreifi sér til miðtaugakerfis eða húðar en hvaða líffæri sem er getur sýkst. ${ }^{1,4}$ Sjúklingar geta verið einkennalausir frá lungum prátt fyrir að upprunalega smitið hafi verið um öndunarveg. ${ }^{1}$ Dreifing til miðtaugakerfis veldur yfirleitt graftarkýlum í heila en sjaldnar heilahimnubólgu. Berist bakterían til húđar veldur hún staðbundinni sýkingu sem getur komið fram sem netjubólga, sýking í húð og sogæðakerfi (e. lymphocutaneous infection) eða með myndun graftarkýlis. ${ }^{1}$ Húðsýking getur einnig orsakast af pví að bakterían komist utan frá gegnum yfirborð húðar, og á pað sérstaklega við einstaklinga með eðlilegt ónæmiskerfi. Einkenni geta verið hin sömu og við húðsýkingu af völdum klasakokka og pví oft rangt meðhöndluð í upphafi sem veldur meðferðartöf eins og sást í umræddu tilfelli. ${ }^{3}$ Einstaklingurinn í sjúkratilfellinu hafði ekki sögu um sár á hendi og pví sennilegra að sýkingin hafi borist frá lungum til húðar eins og algengast er. Áður höfðu greinst hnútóttar íferðir í lungum sem taldar voru vera meinvörp en pegar tilfellið er skoðað eftir á er mögulegt að par hafi verið um að ræða nókardíusýki ílungum sem síðan hafi dreifst til húðar og heila.

Klínískan grun um nókardíusýki er nauðsynlegt að staðfesta með smásjárskoðun og ræktun. Oft parf að beita inngripi til sýnatöku, svo sem berkjuspeglun eða ástungu á heila. Eftir Gramslitun má sjá fínlega granna perlulaga stafi sem eru einnig að hluta til sýrufastir. Greining byggir oft á pessu einkennandi útliti á meðan beðið er eftir ræktun. Ræktun tekur að minnsta kosti prjá sólarhringa og jafnvel allt að prjár vikur. Fjölliðupróf (PCR) gert á sýnum er hraðvirkt og nákvæmt með tilliti til greiningar en er sjaldnast til staðar á rannsóknarstofum. ${ }^{1}$

Meðferð með súlfalyfjum hefur í gegnum tíðina verið mest notuð við nókardíusýki, oftast með trímetóprím/ súlfa. ${ }^{3}$ Aðrir valmöguleikar eru til dæmis merópenem eða imípenem, amikacín, mínocyclín, amoxicillín-klavúlan sýra, ceftríaxón og línezólíð. ${ }^{1-4}$ Algengt er að nota fleiri en eitt lyf saman í upphafi meðferðar vegna samvirkni. ${ }^{2,3}$ Hjá alvarlega veikum sjúklingum mæla sumir með premur lyfjum, og eru pá notuð trímetóprím/súlfa og amikacín ásamt ceftríaxóni eða imípenemi. ${ }^{1}$ Meðferðarlengdin ætti að vera að 
minnsta kosti 12 mánuðir hjá öllum peim sem eru ónæmisbældir eða með sýkingu í miðtaugakerfi, ${ }^{2,5}$ Auk pess er mikilvægt að minnka ónæmisbælingu eins og hægt er, sérstaklega barkstera. Hjá peim sem ekki eru ónæmisbældir eru lungnasýkingar yfirleitt meðhöndlaðar í að minnsta kosti prjá til sex mánuði og húðsýkingar í tvo til fjóra mánuði. ${ }^{2}$ ${ }^{3}$ Oft er hægt að skipta í meðferð um munn eftir prjár til sex vikur en pað fer pó eftir meðferðarsvörun. ${ }^{2}$

Horfur eru háðar útbreiðslu sýkingarinnar. Fyrir tíma sýklalyfja létust nær allir sem fengu nókardíusýki í lungu en nú er líklega hægt að lækna allt að 90\% lungnasýkinga og húðsýkingar má nær undantekningarlaust lækna. ${ }^{1,5}$ Í dreifðum sjúkdómi utan miðtaugakerfis er dánartíðnin á bilinu 20 til $60 \%$ en sé um að ræða sýkingu 1 miðtaugakerfi, eins og hugsanlega var raunin 1 umræddu tilfelli, er hún talin vera frá 40-90\% prátt fyrir meðferð. 3,5

Sjúkratilfellið minnir á að óvenjulegir og sjaldgæfir sýklar geta valdið sýkingum hjá ónæmisbældum sjúklingum á Íslandi og að einkenni og teikn sýkinganna geta líkst peim sem eru af völdum hefðbundinna sýkla eða annarra sjúkdóma. Tilfellið minnir okkur einnig á að hár aldur, illkynja sjúkdómar og meðferð með sykursterum geta valdið verulegri ónæmisbælingu. Mikilvægt er fyrir lækna að vera vel vakandi fyrir óvanalegum sýkingum eins og nókardíusýki í ónæmisbældum einstaklingum.

\section{Heimildir}

1. Brown-Elliott BA, Brown JM, Conville PS, Wallace RJ. Clinical and laboratory features of the Nocardia spp. based on current molecular taxonomy. Clin Microb Rev 2006; 19: 259-82.

2. Lerner PI. Nocardiosis. Clin Infect Dis 1996; 22: 891-905.

3. Lederman ER, Crum NF. A case series and focused review of nocardiosis. Medicine 2004; 83: 300-13.

4. Minero MV, Marín M, Cercenado E, Rabadán PM, Bouza E, Muñoz P. Nocardiosis at the turn of the century. Medicine 2009; 88:250-61.

5. Martínez R, Reyes S, Menéndez R. Pulmonary nocardiosis: risk factors, clinical features, diagnosis and prognosis. Curr Opin Pulm Med 2008; 14: 219-27.

\section{Nocardiosis in immunocompromised host presenting as cellulitis}

Background: Nocardia is a rare pathogen of mainly immunocomprised patients. Only two cases of nocardiosis have previously been identified in Iceland.

Case description: A 92-year-old male on glucocorticoid therapy with metastatic bladder cancer presented with two weeks history of progressive swelling and erythema of the hand and deteriorating cognitive functioning. A brain lesion and pulmonary nodules were identified and Nocardia

Asgeirsson $H$, Sigurdardottir $B$.

Nocardiosis in immunocompromised host presenting as cellulitis.

Icel Med J 2010; 96: 423-5.

Key words: Nocardiosis, nocardia, immunosuppression.

Correspondence: Bryndís Sigurðardóttir, bryndsig@landspitali.is farcinia was cultured from a hand abscess. The patient was initially treated with trimethoprim/sulfamethoxazole but because of rapid deterioration and old age an end-oflife decision was made.

Conclusion: This case of nocardiosis illustrates the importance of uncommon opportunistic infections in immunocompromised Icelandic patients. 